\title{
APOLIPOPROTEIN E4 AND ALZHEIMER'S DISEASE IN SÃO PAULO - BRAZIL
}

\author{
OSVALDOP. ALMEIDA*, CARLOS M. SHIMOKOMAKI**
}

\begin{abstract}
Several recently published studies showed the existence of an association between the allele $\varepsilon 4$ of the apolipoprotein $E$ and Alzheimer's disease $(A D)$ in developed countries. We examined this association in 55 patients with possible or probable $\mathrm{AD}$ and 56 elderly controls referred to outpatient clinics at the "Hospital das Clínicas da Faculdade de Medicina da Universidade de São Paulo" and "Centro de Saúde Escola da Faculdade de Saúde Pública da Universidade de São Paulo". The allele $\varepsilon 4$ was significantly more frequent among patients than controls $(20.9 \%$ vs $8.9 \%, p=0.038$ ). Thirty-six percent of the cases presented with at least one allele $\varepsilon 4$ compared with only $17.9 \%$ of the controls ( $p=0.027$ ). The presence of at least one $\varepsilon 4$ allele increased by 2.63 times the risk of subjects being diagnosed as suffering from AD. All three $\varepsilon 4 \varepsilon 4$ patients were male and had a pre-senile onset of the disease. There was no significant difference between senile and pre-senile cases (41.9\% vs $29.2 \%, \mathrm{p}=0.326$ ) nor between men and women ( $36.0 \%$ vs $36.7 \%, \mathrm{p}=0.959$ ) regarding their risk of being $\varepsilon 4$. The age at onset of symptoms did not differ among the different genotype groups, although $\varepsilon 4 \varepsilon 4$ cases showed a consistent trend for earlier onset. When only patients with the diagnosis of "probable $A D$ " were included in the analysis $(n=43)$, we observed that $22.1 \%$ of the alleles were $\varepsilon 4$, a rate that was significantly higher than the $8.9 \%$ of controls ( $p=0.024$ ). This study supports the association between the presence of the $\varepsilon 4$ allele and $A D$ and extend this finding to Brazilian patients. Nonetheless, the presence of this allele is not necessary nor sufficient for the development of the disease and it is possible that its contribution to the pathogenesis of the disorder depends on the subject's ethnic group.
\end{abstract}

KEY WORDS: dementia, Alzheimer's disease, risk factors, apolipoprotein E, ApoE4.

\section{Apolipoproteína E 4 e doença de Alzheimer em São Paulo - Brasil}

RESUMO - Vários estudos publicados durante os últimos dois anos demonstraram a existência de uma forte associação entre o alelo $\varepsilon 4$ da apolipoproteína $\mathrm{E}$ e a doença de Alzheimer (AD) em países do hemisfério norte. Este estudo investigou a associação entre a presença do alelo $\varepsilon 4$ da apolipoproteína $E$ e a doença de Alzheimer em amostra de pacientes brasileiros atendidos em um serviço público de saúde. Foram investigados 55 pacientes com diagnóstico de AD possível ou provável e 56 controles idosos atendidos em serviços ambulatoriais do Hospital das Clínicas da Faculdade de Medicina da Universidade de São Paulo e do Centro de Saúde Escola da Faculdade de Saúde Pública da Universidade de São Paulo. A determinação do tipo de alelo foi feita através de tipagem genética. Do total de alelos investigados $(n=222)$ observou-se um excesso de $\varepsilon 4$ entre os pacientes $(20,9 \%$ vs $8,9 \%, p=0,038)$, com $36,4 \%$ deles exibindo ao menos 1 alelo $\varepsilon 4$ (vs $17,9 \%$ dos controles, $p=0,027$ ). $O$ risco de indivíduos com ao menos 1 alelo $\varepsilon 4$ serem diagnosticados como sofrendo de AD foi 2,63 vezes maior que para aqueles sem este alelo. Três pacientes apresentaram o genótipo $\varepsilon 4 \varepsilon 4$, sendo todos homens com início pré-senil da doença. Nẫo se observou diferença na frequência de ao menos 1 alelo $\varepsilon 4$ entre pacientes com demência senil e pré-senil $(41,9 \%$ vs $29,2 \%, p=0,326)$ ou entre homens e mulheres $(36,0 \%$ vs $36,7 \%, p=0,959)$. Não havia diferença significativa quanto à idade de início dos sintomas entre grupos de pacientes com diferentes genótipos, embora indivíduos com genótipo $\varepsilon 4 \varepsilon 4$ revelassem tendência a desenvolver a doença mais precocemente. Quando apenas pacientes com diagnóstico de AD provável foram incluídos na análise ( $\mathrm{n}=43$ ), verificou-se que $22,1 \%$ dos alelos eram $\varepsilon 4$, uma taxa significativamente maior que os $8,9 \%$ dos controles $(p=0,024)$. Os resultados deste estudo confirmam a associação entre $\varepsilon 4$ e AD e estendem este achado para uma amostra de pacientes brasileiros. Entretanto, a presença desse alelo não é necessária nem suficiente para o desenvolvimento da doença e é possível que sua contribuição varie de acordo com o grupamento étnico ao qual pertence o indivíduo.

PALAVRAS-CHAVE: demência, doença de Alzheimer, fatores de risco, apolipoproteína E, ApoE4.

* Departamento de Psiquiatria da Faculdade de Medicina da Universidade de São Paulo (USP); **Laboratório de Genética do Instituto de Biologia da USP. Aceite: 15-outubro-1996.

Dr. Osvaldo P. Almeida - Unidade de Idosos (UNID), Departamento de Saúde Mental, Faculdade de Ciências Médicas da Santa Casa de São Paulo - Rua Dr. Cesário Motta Jr 112 - 01277-000 São Paulo SP - Brasil. E-mail: Oswalm@ibm.net. 
Alzheimer's disease is the most frequent cause of dementia, with an estimated prevalence of $5-10 \%$ for those aged 65 years or older and as high as $47 \%$ for those above the age of $85^{4,10}$. The disease progresses insidiously with impairment of memory, language, praxis, and visuo-spatial and other cognitive abilities. The neuropathological substrate of the disorder includes the deposition of amyloid in senile plaques and the development of neurofibrillary tangles ${ }^{1,2,15}$. Environmental ${ }^{54}$ and genetic factors ${ }^{7,25}$ have been considered as possible causes of the disorder.

Familial cases with early-onset $\mathrm{AD}$ were recently associated with a number of mutations of the amyloid precursor protein (APP) gene on chromosome $21^{6,13,17,26,28}$, mutations on chromosome $1^{20-22.37}$, and, more often, with the S182/PS1 gene on chromosome 144. Furthermore, a strong association between the apolipoprotein $\mathrm{E}(\mathrm{ApoE})$ locus on chromosome 19 was described for the more common late onset disease form ${ }^{32}$.

ApoE is associated with the metabolism and clearance of cholesterol and other low-density lipoproteins (LDL) and has a central role in the regeneration of the nervous system ${ }^{5,23,50}$. The ApoE gene is located on the long arm of chromosome 19 and can present with three allelic variants (types 2,3 , and 4 ) and five common genotypes (2/3, 2/4, 3/3, 3/4, and 4/4). The ApoE type 4 allele ( 84 ) seems to increase the risk of late-onset $\mathrm{AD}$ in a dose-related fashion ${ }^{40}$, with the discase starting earlier in patients with two $\varepsilon 4$ alleles $^{52}$. The association between the allele $\varepsilon 4$ and AD has been considered so strong that St. George-Hyslop and colleagues ${ }^{46}$ suggested that the absence of $\varepsilon 4$ may delay or even avoid the manifestation of $A D$ in subjects with pathological mutations on chromosome 21. Others suggested that it is not so much the presence of $\varepsilon 4$ but the absence of $\varepsilon 2$ that contributes to the development of the disease ${ }^{41.48}$.

There are reports suggesting that the distribution of $\varepsilon 4$ varies according to the ethnic group ${ }^{53}$, in which case one would expect different prevalence rates of AD or patterns of $\varepsilon 4$ distribution across the World. This study aimed to evaluate the association between ApoE alleles and AD in a heterogeneous ethnic sample of Brazilian subjects.

\section{METHODS}

\section{Subjects}

Patients with diagnosis of possible or probable AD according to NINCDS/ADRDA criteria ${ }^{24}$ were recruited from two outpatient clinics at the "Hospital das Clínicas da Faculdade de Medicina da USP". Elderly controls aged 65 or older were selected from the Geriatric Outpatient Clinic at the Primary Care Unit of the "Faculdade de Saúde Pública da USP". Those with previous history of mental disorder or with Abbreviated Mental Test (AMTS ${ }^{51}$ ) scores of 7 or less were excluded from the study. This criteria was chosen to decrease the risk of including early AD cases among controls.

\section{Procedures}

\section{Clinical assessment}

Subjects were assessed systematically and all clinical information was then used to select patients classified as possible or probable AD by the NINCDS/ADRDA criteria ${ }^{24}$.

The assessment of family history of dementia involved the collection of information on grandparents, parents, uncles/aunts, brothers/sisters, and children from two qualified informants (spouse, children, brothers/ sisters). However, this information was not analysed because of uncertainties and inconsistencies between informants.

\section{Genetic analysis}

Blood samplos were sent to the Genetic laboratory of the "Instituto de Biociências da USP" for DNA extraction. ApoE allelic type was determined by standard procedures ${ }^{14.55}$.

\section{Data analysis}

The data were analysed with the "Statistical Package for the Social Sciences for Windows 5.0" (SPSS/ $\mathrm{PC}+5.0$ for Windows). Likelihood ratio analysis of contingency tables was used in the investigation of categorical variables (e.g., frequency of the different alleles among patients and controls), the statistical result being distributed 
as chi-square $\left(\chi^{2}\right)$. The odds ratio was calculated when appropriate. Student's t-test was used to compare the means of continuous variables of two different groups (e.g., age). Nonparametric Kruskal-Wallis oneway analysis of variance was used to compare ordinal variables of different groups (e.g., age at onset for patients with 0,1 , or $2 \mathrm{E} 4$ alleles), the statistical result being distributed as chi-square $\left(\chi^{2}\right)$. Nonparametric $U$ test of Mann-Whitney was employed for the analysis of ordinal data of two different groups, the normal statistical result being referred to as " $\mathrm{z}$ ". Ninety-five percent confidence intervals were estimated for the mean $(\mathrm{CI})$, difference between the means $\left(\mathrm{Ci}_{\mathrm{d}}\right)$, and odds ratio $\left(\mathrm{CI}_{\mathrm{oR}}\right)$.

\section{RESULTS}

Fifty-five patients and 56 controls fulfilled the entry criteria of the study; $54.5 \%$ and $69.6 \%$ of them respectively were women $\left(\chi^{2}=2.70, \mathrm{df}=1, \mathrm{p}=0.100 ; \mathrm{OR}=1.91, \mathrm{CI}_{\mathrm{OR}}=0.87\right.$ to 4.16$)$. The mean age of patients and controls were 68.31 ( $\mathrm{Cl}=65.90$ to 70.71 ; range: $45-89)$ and $75.02(\mathrm{Cl}=73.73$ to 76.30; range: $67-84)$, with patients being significantly younger than controls $(t=4.93, d f=82.60$, $\mathrm{p}<0.001, \mathrm{Cl}_{\mathrm{d}}=4.00$ to 9.42 ). The mean age at onset of symptoms was 64.71 ( $\mathrm{CI}=62.29$ to 67.12 ), with the disease starting after the age of 65 (senile AD) in $56.4 \%$ of patients.

Of the total number of alleles ( $\mathrm{n}=222), 6.3 \%, 78.8 \%$ and $14.9 \%$ were $\varepsilon 2, \varepsilon 3$ and $\varepsilon 4$ respectively, patients being more likely than controls to display the $\varepsilon 4$ allele $\left(20.9 \%\right.$ vs $8.9 \% ; \chi^{2}=6.53, \mathrm{df}=2$, $\mathrm{p}=0.038$ ). In fact, $36.4 \%$ of patients had at least one $\varepsilon 4$ allele compared to only $17.9 \%$ of controls $\left(\chi^{2}=4.89, \mathrm{df}=1, \mathrm{p}=0.027 ; \mathrm{OR}=2.63, \mathrm{CI}_{\mathrm{OR}}=1.09\right.$ to 6.31$)$. Table 1 shows the genotype and allelic distribution of patients and controls.

There was no significant difference on the $\varepsilon 4$ frequency distribution between patients with pre-senile ( 24 cases) and senile dementia ( 32 cases) $\left(29.2 \%\right.$ vs $41.9 \% ; \chi^{2}=0.96, \mathrm{df}=1, \mathrm{p}=0.326$; $\mathrm{OR}=1.75, \mathrm{Cl}_{\mathrm{OR}}=0.56$ to 5.44 ). All three $\varepsilon 4 \varepsilon 4$ subjects were classified as cases, with onset of symptoms at the age of 53,59 and 61 years. Among patients $36.0 \%$ of men and $36.7 \%$ of women had at least one $\varepsilon 4$ allele, although all $\varepsilon 4 \varepsilon 4$ were male $\left(\chi^{2}=4.94, \mathrm{df}=1, \mathrm{p}=0.026\right)$. Kruskal-Wallis oneway analysis of variance showed an age at onset difference between patients with 0,1 and $2 \varepsilon 4$ alleles $\left(\chi^{2}=5.64\right.$, $\mathrm{df}=2, \mathrm{p}=0.059$ ). This difference was due to the fact that cases with 2 alleles had an earlier onset than

Table 1. ApoE genotypes and allele frequency among AD patients (possible + probable) and elderly controls.

\begin{tabular}{lccc}
\hline & $\begin{array}{c}\mathrm{AD}(\%) \\
\mathrm{n}=55\end{array}$ & $\begin{array}{c}\text { Controls(\%) } \\
\mathrm{n}=56\end{array}$ & $\mathrm{p}$ value \\
\hline Genotype & 5.5 & 0 & 0.038 \\
$\varepsilon 4 \varepsilon 4$ & 27.3 & 17.9 & 0.234 \\
$\varepsilon 4 \varepsilon 3$ & 3.6 & 0 & 0.092 \\
$\varepsilon 4 \varepsilon 2$ & 54.5 & 69.6 & 0.100 \\
$\varepsilon 3 \varepsilon 3$ & 9.1 & 12.5 & 0.562 \\
$\varepsilon 3 \varepsilon 2$ & 0 & 0 & - \\
$\varepsilon 2 \varepsilon 2$ & & & 7 \\
$\varepsilon 4 \varepsilon^{*}$ & 36.4 & 17.9 & 0.027 \\
$\varepsilon^{*} \varepsilon^{*}$ & 63.6 & 82.1 & \rfloor \\
Allele & $\mathrm{n}=110$ & $\mathrm{n}=112$ & \\
$\varepsilon 4$ & 20.9 & 8.9 & 7 \\
$\varepsilon 3$ & 72.7 & 84.8 & 0.038 \\
$\varepsilon 2$ & 6.4 & 6.3 & \rfloor \\
\hline
\end{tabular}

*represents alleles 2 or 3 (the $3 \varepsilon 4 \varepsilon 4$ patients were included in the $\varepsilon 4 \varepsilon^{*}$ group). 
Table 2. ApoE genotypes and allele frequency among $A D$ patients (probable) and elderly controls.

\begin{tabular}{|c|c|c|c|}
\hline & $\begin{array}{c}\mathrm{AD} \\
\mathrm{n}=43\end{array}$ & $\begin{array}{c}\text { Controls } \\
n=56\end{array}$ & $P$ value \\
\hline Age (mean; $\mathrm{CI}$ ) & $\begin{array}{c}69.02 \\
66.28 \text { to } 71.76\end{array}$ & $\begin{array}{c}75.02 \\
73.73 \text { to } 76.30\end{array}$ & $<0.001$ \\
\hline Female sex & $62.8 \%$ & $69.6 \%$ & 0.474 \\
\hline \multicolumn{4}{|l|}{ Genotype } \\
\hline$\varepsilon 4 \varepsilon 4$ & $7.0 \%$ & 0 & 0.079 \\
\hline$\varepsilon 4 \varepsilon 3$ & $25.6 \%$ & $17.9 \%$ & 0.353 \\
\hline$\varepsilon 4 \varepsilon 2$ & $4.7 \%$ & 0 & 0.186 \\
\hline$\varepsilon 3 \varepsilon 3$ & $51.2 \%$ & $69.6 \%$ & 0.061 \\
\hline$\varepsilon 3 \varepsilon 2$ & $11.6 \%$ & $12.5 \%$ & 0.895 \\
\hline$\varepsilon 2 \varepsilon 2$ & 0 & 0 & $\overline{7}$ \\
\hline$\varepsilon 4 \varepsilon^{*}$ & $37.2 \%$ & $17.9 \%$ & 0.052 \\
\hline$\varepsilon^{*} \varepsilon^{*}$ & $62.8 \%$ & $82.1 \%$ & \rfloor \\
\hline Allele & $n=86$ & $\mathrm{n}=112$ & \\
\hline$\varepsilon 4$ & 22.1 & $8.9 \%$ & 7 \\
\hline $\mathbf{E 3}$ & $69.8 \%$ & $84.8 \%$ & 0.025 \\
\hline$\varepsilon 2$ & $8.1 \%$ & $6.3 \%$ & \rfloor \\
\hline
\end{tabular}

*represents alleles 2 or 3 (the $3 \varepsilon 4 \varepsilon 4$ patients were included in the $\varepsilon 4 \varepsilon^{*}$ group).

$\mathrm{Cl}$, confidence interval of the mean.

patients with just 1 allele (mean age of onset $=57.67$ vs $68.17 ; \mathrm{z}=-2.22, \mathrm{p}=0.026$ ). However, there was no significant age at onset difference between genotype groups (i.e., $\varepsilon 2 \varepsilon 3, \varepsilon 3 \varepsilon 3, \varepsilon 2 \varepsilon 4, \varepsilon 3 \varepsilon 4$, and $\varepsilon 4 \varepsilon 4)\left(\chi^{2}=5.92, \mathrm{df}=4, \mathrm{p}=0.204\right)$.

The exclusion of patients with the diagnosis of "possible AD" from the analysis (12 patients) did not produce significant changes in our results (Table 2).

\section{DISCUSSION}

The association between ApoE type 4 allele and AD has been widely replicated in the developed World during the past two years ${ }^{3,8,12,19,34,40,52}$. Our results confirm the consistency of this association in Brazil, with $36.4 \%$ of patients exhibiting at least one $\varepsilon 4$ allele. Moreover, the presence of this allele increased the risk of subjects being classified as AD by 2.6 times. However, only $20.9 \%$ of the total number of alleles of patients were $\varepsilon 4$, a rate lower than the $25-40 \%$ described by previous studies $^{16,18,27,34,52}$. There are three possible explanations for this discrepancy:

1) our sample included a large number of patients with pre-senile dementia, which may have contributed to decrease the total number of $\varepsilon 4$ alleles in our sample ${ }^{18}$. However, we found no $\varepsilon^{4}$ frequency difference between pre-senile and senile cases in our sample, which suggests that the low prevalence of $\varepsilon 4$ cannot be simply explained by age at onset bias. Another possible confounding factor is that the older age of our control group may have led to an overestimation of the difference between patients and controls, as the $\varepsilon 4$ frequency has been shown to decrease with increasing age ${ }^{39}$. The problem with this explanation is that our patients were younger than those described in previous studies and should, therefore, present an even higher $\varepsilon 4$ rate;

2) it is possible that other risk factors, such as poor schooling, were more important in the causation of $\mathrm{AD}$ in our sample than in the studies from developed countries reported so far ${ }^{29,30}$. Conversely, the 
84 allele has been recently associated with lower intellectual achievement ${ }^{11,36,47}$ and reduction in regional brain metabolism of non-demented young subjects ${ }^{45}$, which suggests that lower educational achievement may result from the presence of the $\varepsilon 4$ allele and might be only secondarily associated with AD. There may be other risk factors playing a role in the causation of AD in Brazil, but their characteristics remain elusive;

3) the Brazilian population may have, on the whole, a lower $\varepsilon 4$ frequency than that found in developed Countries. In fact, Uterman $n^{53}$ suggested that the $\varepsilon 4$ distribution rate varies considerably around the World, so that the use of a heterogeneous ethnic sample may have contributed to produce these results. This is, of course, a highly speculative hypothesis, particularly because the $\varepsilon 4$ rates among our controls were similar to those described elsewhere ${ }^{16,27,34,40}$.

The presence of two $\varepsilon 4$ alleles was observed only among the men of our sample. Payami and coworkers $^{31}$ have recently suggested that women are more susceptible to the effects of ApoEA than men, with only 1 allele being sufficient to increase the risk of AD among women whereas 2 would be necessary in men. This hypothesis was questioned by Corder and colleagues ${ }^{9}$ who reported similar effects of ApoE4 among men and women. The results of this study suggest that the difference of $\varepsilon 4$ distribution among men and women was due to the higher prevalence of $\varepsilon 4 \varepsilon 4$ among the former, which reinforces the idea that women might be more vulnerable to the deleterious effects of apoE4.

The presence of two 44 alleles was also associated with an earlier age at onset, which is in line with previously published data ${ }^{8,34,52}$. However, there was no difference regarding the age at onset of symptoms between patients with one or no $\varepsilon 4$ alleles, nor between cases exhibiting different genotypes. These findings contrast with the results of most studies reported to date and can be explained by the relatively small number of patients included in our sample.

Our results indicate that the 64 allele is an important risk factor for AD, although it also shows that its presence is not necessary nor sufficient for the development of the disease ${ }^{35}$. Moreover, the balance between genetic and non-genetic risk factors may vary considerably in different parts of the World and across different ethnic groups. Nonetheless, it is important to clarify the mechanisms by which ApoE4 contributes to the development of the disease. ApoE4 binds to senile plaques ${ }^{42}$ and forms a stable complex with B-amyloid ${ }^{49.50,56}$ and may, therefore, alter the balance between the deposition and clearance of B-amyloid in favour of the formation of senile plaques and vascular amyloid $^{43,57}$. Alternatively, ApoE4 may influence the phosphorilation rate of tau and favour the formation of neurofibrillary tangles ${ }^{38}$. Others ${ }^{48}$ propose that it is not so much the presence of $\varepsilon 4$, but the absence of $\varepsilon 2 / 3$ that render patients more susceptible to the development of $A D$. This model suggests that $\varepsilon 2 / 3$ promote the binding of tau to microtubules stabilising the neurone's cytoskeleton and protecting the protein from abnormal phosphorilation. Conversely, B-amyloid might facilitate the phosphorilation of tau and neurofibrillary tangles. Another possibility is that ApoEA interferes with the metabolism of cholesterol and other lipids and hinders the integrity of synapses. In other words, the compensatory mechanisms of neuronal regeneration may be impaired in patients with an $\varepsilon 4$ allele $^{33}$. It is clearly essential that the mechanisms by which ApoEA contributes to the development of $A D$ are uncovered, as they may represent promising targets for the treatment of the disorder.

Acknowledgements - This study was supported by a grant from FAPESP (94/2158-8) and CNPq. OPA is supported by CNPq. We are grateful to Luciana Vasquez, Prof. Dr. Maria Rita Passos Bueno and Prof. Dr. Mayana Zatz for helping with the molecular analysis of the blood samples; Prof. Dr. Ricardo Nitrini, the staff at the Neurology Outpatient Clinic and at PROTER for helping with the recruitment of patients, and the staff at the "Centro de Saúde Escola da FSP-USP" for helping with the selection of controls.

\section{REFERENCES}

1. Alzheimer A. "Über eine eigenartige Exkrankung der Himrinde" 1907. Translated by Jarvik L, Greenson H, About a peculiar disease of the cerebral cortex. Alzh Dis Assoc Disord 1987;1: 7-8. 
2. Alsheimer A." Ober eigenertige Krankheitsfulle des späteren Alters" 1911. Translaved by Försil H, Levy R. On certain peculiar diseases of old age. Hist Prychiatry 1991;2: 71-101.

3. Anwar N, Lovestone S, Cheetham ME, Levy R, Powell JF. Apolipoprotein E-E4 allele and Alzheimer's disease. Lancet 1993;342: 1308.

4. Bachman DL, Wolf PA, Linn R et al. Prevalence of dementia and probable senile dementia of the Alzheimer type in the Franingham study. Neurology 1992;42: 115-119.

5. Boyles JK, Zoellner CD, Anderson LJ at al. A role for apolipoprotein E, apolipoprotein A-1, and low density lipoprotein receptons in cholesterol transport during regeneration and remyelination of rat rciatic nerve. J Clin Inveat 1989;83: 1015-1031.

6. Chartier-Harlin MC, Craw ford F, Houlden H et al. Early onset Alzheimer's disease caused by mutations at codon 717 of the B-amyloid precursor gene. Nature 1991;353: 844-846.

7. Clark RF, Goate AM. Molecular genetics of Alzheimer's disease. Arch Neurol 1993;50: 1164-1172.

8. Corder EH, Saunders AM, Strittmatter WJ et al. Gene doses of apolipoprotein E type 4 allele and the risk of Alzheimer's disease in late onset families. Science 1993;261: 921-923.

9. Corder EH, Saunders AM, Strittmatter WJ et al. The apolipoprotein E E4 allele and sex-specific risk of Alzheimer's disease. I Am Med Assoc 1995;273: 373-374.

10. Evans DA, Funkenstein H, Albert MS et al. Prevalence of Alzheimer's disease in a community population of older persons. J Am Med Assoc 1989;262: 2551-2556.

11. Feskens EJM, Havekes LM, Kalmijn S, Knijff P, Launer LJ, Krombout D. Apolipoprotein $\& 4$ allek and cognitive decline in elderly men. Brit Med J 1994;309: 1202-1206.

12. Forrtl H, Crech C, Sattel H et al. Apolipoprotein E und Alzheimer-Demenz. Nervenarzt 1994;65: 780-786.

13. Gonte A, Chartier-Halin MC, Mullan M et al. Segregation of a missense mutation in the amyloid precursor protein gene with familial Alaheimer's diveace. Nature 1992;349: 704-706.

14. Gwo C, Marynen P, Cassiman IJ. A rapid, semiautomated method for apolipoprotein E genotyping. PCR Meth Applicat 1993;2: 348-350.

15. Hardy JA, Allsop D. Amyloid deposition as the central event in the setiology of Alzheimer's discase. TiPS 1991;12: 383-388.

16. Hendrie HC, Hall KS, Hui S at al. Apolipoprotein E genotypes and Azlheimer's disease in a community study of elderly African Americans. Ann Neurol 1995;37: 118-120.

17. Jones CT, Morris S, Yates CM et al. Mutation in codon 713 of the B-amyloid precursor protein gene presenting with schizophrenia Nanure Genet 1992;1: 306-309.

18. Kawaman J, Tanaka S, Shimohama S, Ueda K, Kimura J. Apolipoprotein E polymorphism in Japanese patientes with Alzbeimer's disease or vascular dementia. J Neurol Neurosurg Psychiary 1994;57:1414-1416.

19. Kunvisto J, Koivisto K, Kervinea $\mathrm{K}$ at al. Association of apolipoprotein E phebotypes with late onset Alzheimer's disease: population based study. Br Med J 1994;309: 636-638.

20. Levy-Lahad E, Wasco W, Poorkaj P et al. Candidate gene for the chromosome 1 familial Alzheimer's disease locus. Science 1995;269: 973-977.

21. Levy-Lahad E, Wijaman EM, Nemens E et al. A familial Alzheimer's disease locus on chromosome 1. Science 1995;269: 970-973.

22. LU J, Ma J, Pouter H. Identification and expression analysis of a polential familial Alzheimer disease gene on chromosome 1 related to AD3. Proc Nat Acad Sci USA 1995:92:12180-12184.

23. Mahley RW. Apolipoprotein E: cholesterol transport protein with expanding role in cell biology. Science 1988;240; 622-630.

24. McKhann G, Drechman D, Folstein M, Katzman R, Price D, Stadlan EM. Clinical diagnoais of Alzheimer's disease: report of the NINCDS/ADRDA workgroup under the suppices of the depertment of Health and Human services task force on Azheimer's diseave. Neurology 1984;34: 939-944.

25. McLoughlin DM, Lovestone S. Alzheimer's disease: recent advances in molecular pathology and genetics. Int J Geriatr Prychiatry 1994;9:431-444.

26. Mullan $M$, Houlden $H$, Windelspech $M$ a al. A locus for familial early-onset Alzheimer's disease on the long arm of chromosome 14, proximal to the al-antichymotrypsin gene. Nature Genet 1992; 2:340-342.

27. Muramatru T, Higuchi S, Arai H et al. Apolipoprotein E 84 alkele distribution in alcoholic dementia and in Alzheimer's disease in Japan. Ann Neunol 1994;36: 797-799.

28. Murel J, Furlow M, Ghetti B, Beneon MD. A mutation in the amyloid precursoc protein associated with hereditary Alzheimer's diseace. Science 1991;254:97-99.

29. Orrell M, Sahakin B. Education and dementia: research evidence supports the concept "use or loose it". Br Med J 1995;310: 951-952.

30. Ot A, Breteler MMB, van Harskamp F et al. Prevalence of Alzheimer's disease and vascular dementia: association with education - the Rotterdam study. Br Med J 1995;310: 970-973.

31. Payami H, Montee KR, Kaye JA et al. Alzheimer's disease, apolipoprotein E4, and gender. J Am Med Assoc 1994;271: 1316-1317.

32. Pericak-Vance MA, Bebout JL, Gasken PCJr. et al. Linkage studies in familial A tzheimer's discase: evidence for chromosome 19 linkage. Am J Hum Genet 1991;48: 1034-1050.

33. Poirier J. Apolipoprocein E in animal models of CNS injury and in Alzheimer's disease. TNS 1994;17: 525-530.

34. Poirier J, Davigoon J, Bouthillier D, Kogan S, Bertrand P, Gauthier S. Apolipoprotein E polymorphism and Alzheimer's disease. Lancet 1993;342: 697-699.

35. Rebeck GW, Perls TT, West HL, Sodhi P, Ljpaiz LA, Hyman BT. Reduced apolipoprotein E4 allele frequency in the oldest old Alzheimer's patients and cognitively normal individuals. Neurology 1994;44: 1513-1516.

36. Reed T, Carmelli D. Swan GE et al. Lower cognitive performance in normal older adult male twins carrying the apolipoprotein E eA allele. Arch Neurol 1994:51: 1189-1192. 
37. Rogaev EI, Sherrington R, Rogaeva EA et al. Familial Alzheimer's disease in kindreds with missense mutations in a gene on chromosome 1 related to the Alzheimer's disease type 3 gene. Nature 1995;376; 775-778.

38 Roses AD. Apolipoprotein $\mathrm{E}$ affects the rate of Alzheimer disease expression: $\boldsymbol{B}$-amyloid burden is a secondary consequence dependent on ApoE genotype and duration of disease. J Neuropathol Exp Neurol 1994;53: 429-437.

39. Roses AD, Strittmatter WJ, Pericak-Vance M, Corder EH, Saunders AM, Schmechel DE. Clinical application of apolipoprotein E genotyping to Alzheimer's disease. Lancet 1994;343: 1564-1565.

40. Saunders AM, Strittmatter WJ, Schmechel D et al. Association of apolipoprotein E allele $\varepsilon 4$ with late onset familial and sporadic Alzheimer's disease. Neurology 1993;43: 1467-1472.

41. Schachter F, Faure-Delanef $L$, Guenot $F$ et al. Genetic associations with human longevity at the ApoE and ACE loci. Nature Genet 1994;6: 29-33.

42. Schmechel DE, Saunders AM, Strittmatter WJ et al. Increased amyloid B-peptide deposition in cerebral cortex as a consequence of apolipoprotein E genotype in late-onset Alzheimer disease. Proc Nat Acad Sci USA 1993;90: 9649-9653.

43. Selkoe DJ. Alzheimer's disease: a central role for amyloid. J Neuropathol Exp Neurol 1994;53: 438-447.

44. Sherrington R, Rogaev EI, Liang Y et al. Cloning of a gene bearing missense mutations in early-onset familial Alzheimer's disease. Nature 1995;375: 754-760.

45. Small GW, Mazziotta JC, Collins MT et al. Apolipoprotein E type 4 allele and cerebral glucose metabolism in relatives at risk for familial Alzheimer disease. J Am Med Assoc 1995;273: 942-947.

46. St. George-Hyslop P, McLachlan DC, Tuda T, Rogaev E. Alzheimer's disease and possible gene interaction. Science 1994;263: 537.

47. Stern Y, Alexander GE, Prohovnik I, Mayeux R. Inverse relationship between education and parietotemporal perfusion deficit in Alzheimer's disease. Ann Neurol 1992;32: 371-375.

48. Strittmatter WJ. In: Meeting Briefs - Neuroscientists reach a critical mass in Washington. Science 1993;262;1210-1211.

49. Strittmatter WJ, Saunders AM, Schmechel D et al. Apoplipoprotein E: high avidity binding to the B-amyloid and increased frequency of type 4 allele in late onset familial Alzheimer's disease. Proc Nat Acad Sci USA 1993;90: $1977-1981$.

50. Strittmatter WJ, Weisgraber H, Huang DY et al. Binding of human apoplipoprotein E to synthetic amyloid B peptide: isoform-specific effects and implications for late onset Alzheimer disease. Proc Nat Acad Sci USA 1993;90: 8098-8102.

51. Thompson P, Blessed G. Correlation between the 37 item Mental Test Score and abbreviated 10-item Mental Test Score by psychogeriatric day patients. Br J Psychiatry 1987;151: 206-209.

52. Tsai MS, Tangalos EG, Petersen RC et al. Apolipoprotein E: risk factor for Alzheime disease. Am J Hum Genet 1994;54: 643-649.

53. Utermann G. The apolipoprotein E connection. Curr Biol 1994;4: 362-365.

54. Van Duijn CM, Stijnen T, Hofman A. Risk factors for Alzheimer's disease: overview of the EURODEM collaborative reanalysis of case-control studies. Int J Epidemiol 1991;20: S4-S12.

55. Wenham PR, Price WH, Blundell G. Apolipoprotein E genotyping by one-stage PCR. Lancet 1991;337: 1158-1159.

56. Wisniewski T, Frangione B. Apolipoprotein E: a pathological chaperone protein in patients with cerebral and systemic amyloid. Neurosci Lett 1992;135: 235-238.

57. Zubenko GS, Stiffler S, Stabler S et al. Association of the apolipoprotein E $\varepsilon 4$ allele with clinical subtypes of autopsyconfirmed Alzheimer's disease. Am J Med Genet 1994;54: 199-205. 